$1-1-1936$

\title{
Service to agriculture : a report of the West Virginia Agricultural Experiment Station for the biennium ending June 30, 1936.
}

F. D. Fromme

Follow this and additional works at: https://researchrepository.wvu.edu/ wv_agricultural_and_forestry_experiment_station_bulletins

\section{Digital Commons Citation}

Fromme, F. D., "Service to agriculture : a report of the West Virginia Agricultural Experiment Station for the biennium ending June 30, 1936." (1936). West Virginia Agricultural and Forestry Experiment Station Bulletins. 278.

https://researchrepository.wvu.edu/wv_agricultural_and_forestry_experiment_station_bulletins/279 @ WVU. It has been accepted for inclusion in West Virginia Agricultural and Forestry Experiment Station Bulletins by an authorized administrator of The Research Repository @WVU. For more information, please contact ian.harmon@mail.wvu.edu. 
West Virginia University Libraries In||

308021005212247 



\section{Service to Agriculture}

Report of the West Virginia Agricultural

Experiment Station for the Biennium

Ending June 30, 1936 


\section{Agricultural Experiment Station StafF}

C. S. BOUCHER, Ph. D., LL. D., President of the University

F. D. FROMME, Ph. D. ................ Dean and Directur GERALD JENNY, M. S., Agricultural Editor..... JOHN C. JOHNSTON, Chief Clerk

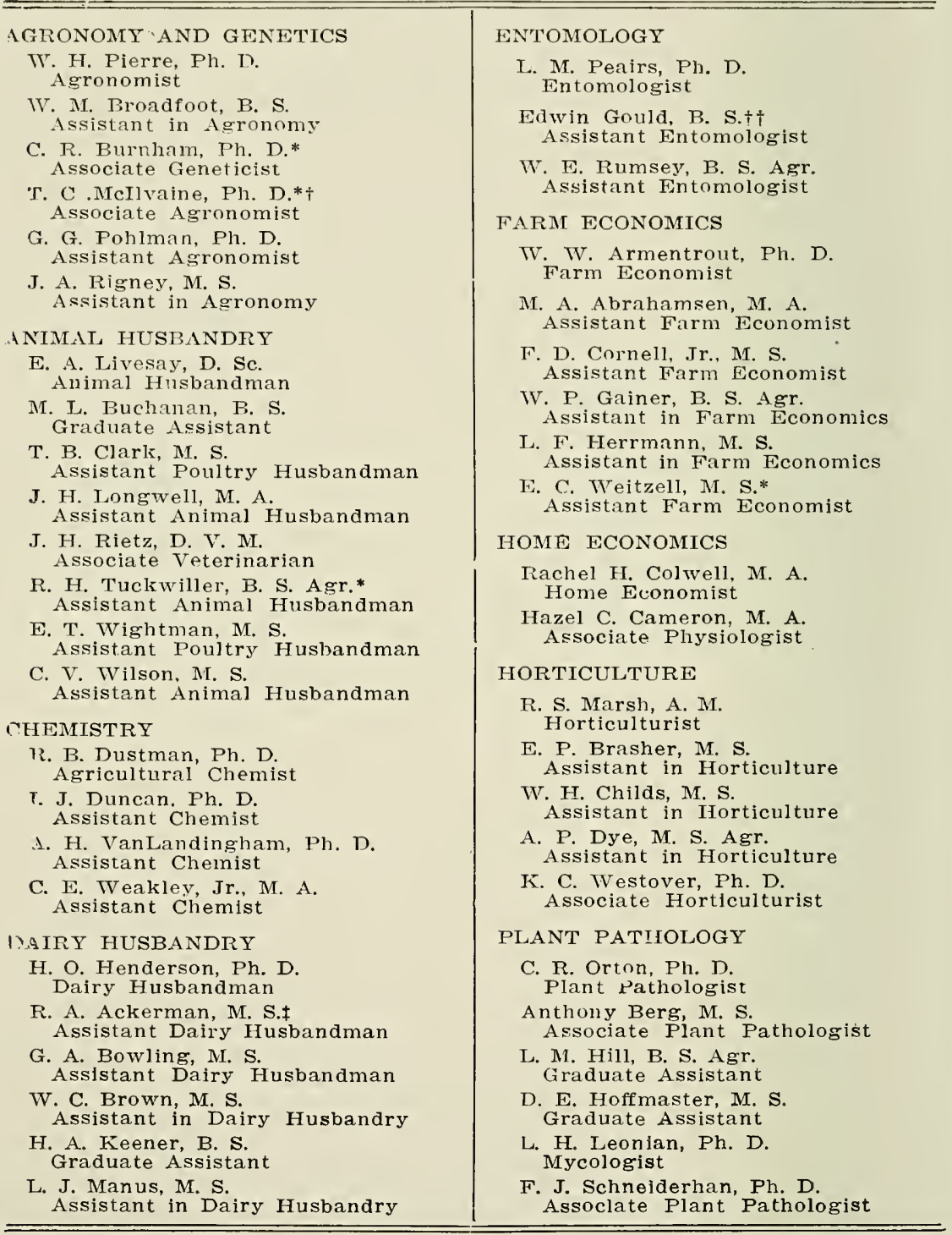

*In cooperation with the U. S. Department of Agrlculture, Washington, D. C. tIn charge of the Lakin Experiment Farm, Lakin, W. Va. IIn charge of the Reymann Memorial Farms, Wardensville, W. Va. $t+$ In charge of the University Experiment Farm, Kearneysville, W. Va. 


\section{Service to Agriculture}

The service of the University to the agriculture of West Virginia $\boldsymbol{I}$ is through a comprehensive program of resident instruction, extension work, and research designed so as to promote the agricultural development of the state and contribute to the welfare of the rural population. The research phases of the program are conducted by the Agricultural Experiment Station, which was created jointly by the Federal and State Governments under the Hatch Act of 1887 and the subsequent enabling act of the Legislature. The information gained through research is incorporated in the teachings of the resident and extension staff and by means of these agencies is carried to the farmers of the state and becomes a part of their agricultural practice. Previous reports have discussed some of the far-reaching changes in farm practice which have been brought about through research education and during the half century which has elapsed since the establishment of the Experiment Station, and this report will treat only of the problems and results of experimental work during the past two years.

Major emphasis during this period has been given to the assembly and analysis of data relating to present and future uses of the land resources of the state. The studies have included historical trends in crop and livestock production, the delimitation of regions according to types of farming, the classification of soils according to type, degree of slope, erosion losses, and productivity, and the development of plans for desirable future uses of land areas from the standpoint of soil conservation and sustained economy in production. Much new information has been brought together and has been used in the preparation of maps and production plans which will be published from time to time. It is evident from these studies that certain shifts in production and land use will be necessary if soil resources are to be conserved and adequate standards of production and income are to be maintained. The shifts in production will be toward the growing of more and a better quality of roughage involving the more extensive use of legumes and correlated with increased productivity of the better lands. This means increased use of lime and fertilizers, the use of high yielding, adapted seed, the 
control of diseases and insects, the better management of beef cattle, dairy cows, sheep, and poultry, and the many additional guides to sound and economical farming which have been and are now being worked out through the research program of the Station. Following the upbuilding of the more productive areas it will be possible to convert some of the marginal acreage of crop and pasture lands to forest uses to the advantage of the individual land owner and to the great advantage of the state as a whole, which will profit through soil conservation and flood prevention as well as through a more stable and prosperous farm population.

The study of land resources has brought to particular notice the rapid decline in the productivity of pastures within recent years. Both the volume and feeding quality of pasture grasscs have fallen greatly because of over-grazing and the faihure to return to the soil those elements which are essential to the growth of grasses and which are removed through grazing. The extensive pasture experiments now in progress are pointing the way to the economical rebuilding of these pasture lands, which are the most valuable agricultural resources of the state.

Although the land-use and planning studies have received particular emphasis there has been no neglect of other lines of research and there has in fact been some expansion of the program as a whole within the last year of the biennium, made possible through increased support from federal sources due to the passage of the Bankhear-Jones Act. The new projects which have been established under the Bankhead-Jones funds are titled as follows:

Regional adjustment in farming

Biological and mechanical control of codling moth

Improving market qualities of turkeys by cross breeding

Corn genetics and breeding

The nature and effect of substances which induce or stimulate growth and sexuality in fungi

The latter two projects are of a fundamental or basic nature as included in the scope of the federal Act and deal with principles which may have far-reaching significance. The first of the five projects covers the studies of land resources and agricultural planning, and the other two relate to problems of immediate practical importance the solution of which would supply much needed information to the fruit grower and turkey producer. 
There are in all a total of 65 researeh projects under investigation at this time of which 27 are financed with Purnell funds, 7 with Adams funds, 5 with Bankhead-Jones funds, and 26 are financed jointly with state and Hatch funds. A number of projects are cooperative with the U. S. Department of Agriculture, as will be noted in examining the list of projects appended to this report. It has always been the policy of the West Virginia Station to integrate its work with that of the federal government and of other states having similar problems, so as to avoid unneeessary duplicatiol.

Besides its chief function in the conduet of rescarch and experimentation the Station is ealled upon for a variety of services for which it is espeeially qualified because of trained personnel and facilities. These include the analysis and identifieation of a wide range of materials and the supplying of technieal information on many subjects.

\section{Reports on Current Research}

The following reports eover some of the prineipal features of the eurrent research program in a brief way. More eomplete statemenis will be found in the bulletins, scientific papers, and circulars published during the biennium as listed elsewhere in this report. Copies of the bulletins and eireular's are available for free distribution to residents of the state, and the technical papers are also available in limited numbers for those interested in the material which they present.

\section{CHEMICAL STUDIES}

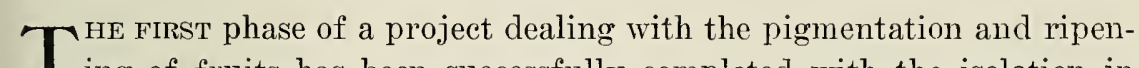
1 ing of fruits has been suecessfully completed with the isolation in pure form of the red eoloring matter from the skins of Winesap apples. The pigment has been identified as idaein ehloride, an anthoeyanin, and is the same substanee which produces the red eolor of eranberry fruits. Because of the very limited quantities of material available after purification the use of micronanalytieal metheds was necessary in order to establish the ehemical eonstitution of the pigment. Now that this is known, field work on the problem of influeneing eolor production in the orehard ean proeeed with greater assurance. Because of the importance of high color from the market standpoint any additional information on the factors which influence color produetion should prove of considerable interest to the large eommercial apple industry of the state.

Ethylene, ethylene ehlorohydrin, and ultraviolet irradiation treatments of stored Rome Beauty, Stayman Winesap, and Ben Davis varie- 
ties were found not to affect materially the chemical composition of the fruit or the acidity of the expressed juices as compared with similarly stored untreated fruits. Ethylene treatment hastened the color change from green to ycllow and likewise accelerated the softening of the apple tissues.

\section{Nitrogen Atmosphere Preserves Black-Walnut Meats}

Search for a method of retarding or preventing the development of rancidity in stored kernels of black walnut included storage trials at three temperatures: (1) unheated cellar storage, (2) storage slightly above freezing, (3) storage below freezing, and under various treatments of nitrogen, hydrogen, carbon dioxide, vapors of ethyl alcohol with air or nitrogen, vacuum, and partial dessication prior to storage in air. The trials also included storage in ordinary screw-cap jars, not air-tight, and in air-tight sealed glass containers. The original flavor and palatbility of the kernels was retained for a period of two years when held in an atmosphere of nitrogen, in sealed containers, at temperatures near the freezing point. Under similar conditions vacuum, hydrogen, and carbon dioxide delayed the development of rancidity but were somewhat less effective than nitrogen. Storage in air-tight containers was superior to storage in screw-cap jars, particularly at ordinary cellar temperatures.

The chemical phases of a number of additional studies are described under other sections of this report and include a wide variety and extent of analyses and determinations dealing with rations for dairy cows and poultry, oxidized flavors in milk, coumarin content of strains of sweet clover, varieties of corn for silage, and the composition of skeletal parts of experimental animals.

\section{ANIMAL HUSBANDRY}

$\mathrm{O}$ NE HUNDRED AND FORTY first-cross Corriedale lambs from native Hampshire-type West Virginia ewes averaged 10 pounds heavier at weaning time (late August) than 60 second-cross lambs. There was little difference between the groups in grade, weight of pelt, or palatability of the meat. This indicated that high-grade Corriedale lambs may require more time to reach desired slaughter weights than the first-cross Corriedales. The first-cross lambs were produced in the period from 1931 to 1933 , the second cross 1933 to 1934 . This work was conducted in cooperation with the Bureau of Animal Industry, U. S. Department of Agriculture. 


\section{Creep-Feeding Calves on Pasture}

Calves creep-fed grain on pasture during the suckling period and slaughtered at weaning time produced lighter-weight carcasses but "dressed" somewhat higher and were fatter or better finished than comparable calves fed no grain prior to weaning followed by grain with alfalfa hay in dry-lot for 116 days after weaning. These differences were shown by a summary of 3 years' work conducted in cooperation with the Bureau of Animal Industry, U. S. Department of Agriculture. The summary also indicated, among other things, that the roasted meat from the younger calves was slightly less tender, according to the mechanical test, and less juicy, according to the palatability committee, than the roasted meat from the older calves.

Comparisons of the feeding value of ensilage made from an ensilage variety of corn, Cocke's Prolifie, and Boone County White, a variety commonly grown for grain, were made in 1935 using both steers and heifers. Larger gains were made on the silage from the Boone County variety on a pound-to-pound dry-matter basis. These results are comparable to those obtained previously. The average yield of dry matter per acre in 1935 was 7588 pounds for Boonc County White and 6246 for Cocke's Prolific.

\section{Grass Does Not Produce Dark Lean in Beef}

Grass-finished cattle commonly are penalized on the market because of the widespread opinion among meat packers and retailers that the beef will be dark. Because of this almost universal objection to grassfed cattle, West Virginia cattlemen, as well as those in adjoining states, often are forced to accept a lower price for their cattle than for grainfed cattle of similar grade.

Color readings were made on beef samples from fat yearlings, 2 year-old, and 3-year-old cattle in experiments at Morgantown and at Lewisburg, the latter in cooperation with the Bureau of Animal Industry, U. S. D. A. A color analyzer was used in making the readings.

Grass as a feed was not found to produce dark lean in beef. The brightness of the lean of beef appeared to be related directly to the degree of finish of the beef. Beef from grass-finished cattle can be expected to be as bright as beef from grain-finished cattle which show a comparable degree of finish. The experiment is described in Bul. 274 of the Station. 
A S the result of three years of trials it seems to be definitely estabA lished that the vitamin-A content of a ration does not modify the susceptibility of pigs to infestation by roundworms. The pigs which were fed. a basal ration supplemented by whole codlivel oil to supply vitamins $A$ and $D$, and those which received ritamin D only in oxygenated codliver oil added to the hasal ration, developed fully as many and as large worms as did those whieh received the basal ration only.

\section{Copper Sulphate for Sheep}

Several years of experiments with solutions of copper sulphate in various concentrations for the control of gastro-intestinal parasites in sheep show that the most satisfactory control, considering simplicity and cost, is obtained with a $1 \frac{1}{2}$ percent solution and that non-fasting reduces the efficiency of the treatment. A one pereent solution was 30 percent less effective in the control of nematodes and was quite inefiective in the treatment of cestodes. Complete control of parasitc infestation was not obtained after 10 months of mass feeding with a $1: 30$ mixture of copper sulphate and salt, and copper sulphate poisoning lesulted in the case of three sheep. A 1:50 mixture was wholly inadequate.

Approximately 200 sheep have been treated for lung worms, using an oil extract of pyrethrum, the dosage being 2 to 3 c.e. of the oil injected intratrocheally. The parasites were removed from 75 percent of the sheep with one injection, two injections were required for 20 percent, and 5 percent required three injections. No fatalities resulted from the injections.

\section{POULTRY HUSBANDRY}

A Study of the factors related to egg weight during the normal life of A an unselected group of White Leghorn hens which has continued for a period of 10 years has now been completed and will be published in full detail in the near future. Of the 200 birds with which the study was begun in the first year, 26 survived by the tenth year, or a survival of 13.8 percent of the original number. There was no relationship between earliness of maturity and longevity, the early maturing birds living as long as the late maturing ones. There was also no relationship between egg production and length of life in the flock. The average egg production per bird declined rather gradually from the first to the tenth year, the number for the first year being 170 , and 23 for the last year. Hens which were high producers in the first year tended to remain com- 
High percentages of slipped tendons and high mortality of White Leghorn ehicks resulted from the feeding in battery brooders of a ration of yellow corn meal, alfalfa leaf meal, meat scraps, and dried buttermilk. These diffieulties were largely corrected and rapid growth was obtained, when wheat bran and middlings or wheat bran, middlings and ground oats were substituted for 30 pereent of the yellow corn meal.

Other work in progress for which eonclusions cannot be stated at this time include (a) studies of the interior quality of eggs (percentare of thick white and yolk color) as affected by rations and methods of feeding grain, (b) studies of the relative values of proteins from different sourees in promoting the growth of young ehicks, and (e) an attempt to improve the market quality of turkeys by eross-breeding.

\section{FRUIT CROPS}

A STUDy has been made as to the number of pollen grains produced $A$ by the commereial varieties of apple. As is well known, the varieties of the Winesap group produce little or no pollen. Delicious and Starking, two particularly efficient pollenizers, produce 6000 to 9000 grains per anther. Cortland and Wealthy although considered good pollenizers produce on an average only 3000-5000 grains per anther. Other varieties fall between these two extremes.

\section{Peach Susceptible to Sudden Temperature Drops}

Studies of winter hardiness of the fruit buds of the peach which have involved some 60 varieties were made in the laboratory using apparatus especially designed for low-temperature control work. It was found that varietal differences are less manifest in the fall and early winter, when the buds are in the rest period, than in late winter and early spring, when developmental changes have taken place. The buds become more tender, however, after a warm spell even in late fall. In 1935 buds of 5 varieties showed slight to severe injury when exposed to $-5^{\circ} \mathrm{F}$. on January 12 , but when the same exposure was repeated on January 21 following several days of $50^{\circ}$ to $60^{\circ}$ temperatures, severe killing resulted. The rate of temperature fall was found to be very important, the most severe injury resulting from sudden drops. The rate of temperature rise following exposure did not, however, appear to be important.

In studies of winter injury of apple fruit-buds it was found that the conducting tissue at the base of the bud is more subject to injury than the bud itself. The center flower of the eluster was often injured at $-16^{\circ}$ $\mathrm{F}$. More flowers were injured at $-25^{\circ} \mathrm{F}$. and a few were still alive after 
exposure to $-32^{\circ} \mathrm{F}$. Rome, MeIntosh, and 'I'ransparent were the hardiest of the varieties tested.

The extensive field tests of apple rootstocks which are loeated chielly at the branch station at Keameysville, and are cooperative with the Bureau of Plant Industry, U. S. D. A., are beginning to show some differences which will doubtless become more apparent as the planting grows older. Early losses in the variety Gallia were much heavier than any other variety and were not confined to any partieular understock. The varieties on dwarfing stocks show differences in growth and blooming as compared with standard stocks, and seem to be shallow-rooter, bending easily from winds and loads of fruit.

The sour cherries on Mazzard stocks generally have greater trunk diameter than those on Mahaleb and have a tendency to bloom earlier. Sweet cherries have suffered severe winter injury, the Tartarian variety showing the greatest injury and the Schmidt variety the least. Winter injury was not related to differences in under-stocks.

\section{Apple Roots go Deep in Limestone Soils}

A large number of exeavations have been made on a number of orehard soils to study the distribution of apple roots. Many roots were found at 8 to 10 feet in depth on the deeper limestone soils, but root penetration was limited to a few feet on the shallow shale soils. Moisture determinations will be made from the different soil profiles.

A comparison of three methods of training young apple trees, viz., heading at 30 inches, single debudding, and group debudding, shows that the debudding methods, particularly single debudding, have a tendency to produce narrow erotch angles in the main seaffold limbs. This was true especially of Rome and Delicious, varieties which naturally tend to form narrow angles. There were no differences in size of the trees trained by these three methods after five years' growth.

The number of varieties of tree and small fruits under trial in 1935 and the location of the plantings is as follows:

$\begin{array}{lccc} & \text { Morgantown } & \text { Kearneysville } & \text { Reedsville } \\ \text { Apples } & 105 & 35 & -- \\ \text { Peaches } & 66 & 26 & -- \\ \text { Plums } & 18 & 8 & -- \\ \text { Cherries } & 38 & 37 & -- \\ \text { Pears } & 27 & -- & -- \\ \text { Strawberries } & -- & -- & 12 \\ \text { Raspberries } & 12 & -- & 12 \\ \text { Grapes } & 95 & -- & 30 \\ \text { Blueberries } & 6 & -- & 7\end{array}$


Fourteen varieties of strawberries were also under trial at Lakin.

Other fruit work in progress includes studies of peach and apple thinning, experiments with different systems of orehard soil culture for apples, peaches, and cherries, nitrogen and potash fertilizer studies with apples, and a study of the effect of subsoiling and dynamiting on growth and yield of apple trees. The latter work shows no significant differences to date.

\section{Cause of Cracking in Stayman Winesap}

The interior of an apple, though apparently of uniform constitution within the fleshy part, is made up of tissues which are not necessarily alike in strength and composition. Immediately beneath the outer skin is a layer of tissue wholly different from that of the flesh. The condition of each of these parts - surface skin, underskin, and flesh coupled with the condition of atmospheric evaporation, seems to have much to do when cracking oceurs in the Stayman Winesap apple.

Tests conducted at the University Experiment Farm at Kearnevsville point to the conclusion that a low rate of evaporation in orchards is the largest single factor responsible for cracking. Sudden and large inereases in content of soil moisture such as follow a downpour of rain were not found to have bearing on the matter. Neither did so-called "root pressure." Neither was any cracking traced to fluctuations of air temperature, no matter how severe.

But given, as one might expect, a condition of little evaporation of moisture for prolonged periods after a rain, cracking could confidently be expeeted in susceptible fruits. This likelihood became a certainty where apple-skin tissue was mechanieally weak from such causes as wind, spray injury, and sunburn.

Studies of the interior of Stayman apples lead the West Yirginia Station to believe that internal pressure is greatest where the skin and underskin are weakest. Under normal atmospheric conditions, wherein moisture can transpire freely through skin tissue to be absorberl by the air, cracking is minimized. But where this free movement of moisture is impeded, pressures are built up within the apple which must firid their way out - and cracking along the weakest points provides the way.

\section{VEGETABLE CROPS}

The rather comprehensive study of the effect of green manure crops in maintaining and building soil fertility when grown in rotations with vegetable crops which is in progress at Lakin has not been in progress long enough to show decided differences exeept that continuous 
eropping with eabbage and tomatoes begins to show less vigorous growth and reduction in yield. Those green manures that ean he seeded after the tomatoes and cabbages are harvested are plowed under early in the spring.

\section{Twin-Row Planting System Superior in Polatoes}

A single-year eomparison of single and twin-row plantings of potatoes showed striking differences in yield in favor of the twin-row system of planting. The plantings were located at Reedsville and Terra Alta and were of the Rural variety. In the single planting the sets were spaced 10 inches apart in the drill row and the same spacing was used in each of the twin rows with 10 inches between the rows and the sets staggered. Further comparisons using both Rural and Cobbler stock and with a range of spacing will be made before final conclusions are reached.

Studies of the effect of fall (sun) greening of potato seed stocks show that no benefits were derived from this practice.

\section{Potatoes Require Complete Fertilizer}

Fertilizer experiments with potatoes, which have included 18 plantings in cooperation with 12 farmers in 1935 and 13 in 1934, show in general (1) that a complete fertilizer is needed, (2) that applications of 1400 pounds per acre of a high-grade fertilizer are not excessive, (3) that fertilizers properly applied in the drill result in larger yields than when they are broadcast, and (4) that magnesium may be a limiting factor in potato production on some of the lighter soils of West Virginia.

Field trials of varieties and strains of vegetable crops which are in progress at Lakin included 350 varieties and strains in 1934 and 270 in 1935. The kinds of vegetables under test were snap beans, bush lima beans, beets, broccoli, cabbage, Chinese cabbage, cauliflower, cucumbers, sweet corn, carrots, eggplant, melons, peppers, early and late squash, chard, potatoes, tomatoes, Brussels sprouts, and peas.

Twenty-seven varieties and strains of sweet com and 20 of cabbage were also under test at Reedsville in 1935.

Results of the trials at Lakin have been made available to growers in Mimeograph Circular No. 12 and those at Reedsville in No. 13.

\section{DAIRY HUSBANDRY}

TUDIES of the feed requirements of dairy animals in recent years have $\checkmark$ pointed especially in the direction of determining the degree in which relatively simple home-grown feed may be substituted for the more complex rations now commonly used. Satisfactory growth was 
made by a group of five heifers on a ration containing the alfalfa plant as the sole source of protein. Three of the animals have calved and are producing a medium flow of milk on this ration. A balance trial with one of them indicates that a positive nitrogen balance can be maintained with alfalfa as the sole souree of protein for an animal producing nearly 30 pounds̀ of milk per day.

In a comparison of a ration of timothy hay, corn meal, and corn gluten meal with a ration of alfalfa hay and corn meal the first-named was inferior for milk production and reproduction. Both rations seemed to support normal growth.

\section{Phosphorus Intake Important in Gestation}

The inorganie phosphorus requirements of dairy heifers during the period of first gestation and lactation were found to be maintained at approximately the normal level with an average daily intake of 11.8 grams of phosphorus, which is equivalent to 1.2 grams per 100 pounds of body weight. In order to meet these requirements it was found that the phosphorus in the feed should exceed that in the milk by 9 to 10 grams per 100 pounds of body weight in the ease of Holstein heifers producing 20 to 30 pounds of milk per day.

The inorganic phosphorus in the blood of animals receiving normal phosphorus rations shows a slight inerease from the second to the fourth month, remains fairly eonstant until the tenth month, and gradually deelines with inereasing age. There is a decided drop at or immediately following parturition, this being especially pronounced in animals on low-phosphorus rations. Such rations cause an immediate lowering of the inorganic phosphorus of the blood but several weeks elapse before the appearance of such physical symptoms as loss of appetite, stiffness in front and rear quarters, and generally emaeiated condition.

A normal growth curve for Ayrshire eattle has been established with the herd at the Reymann Memorial Farms as the result of five years of measurements which involve the weighing and measuring each month of all animals at the farm, an average of 125 animals per month. Useful information on the relation of birth weight to final weight, the relation of size at birth to milk production, the effect of the sire and the dam on size of offspring, and many other relationships should be developed from these studies.

\section{Are Type and Butterfat Production Related?}

Studies of the transmission of body conformation and of milk and butterfat production by sires of the Ayrshire breed constitute one of the 
major research projects at the Reymann Memorial Farms. A plan for recording the scores of the cows on the basis of type was inaugurated in 1935 under which each animal is seored and photographed onee a year on a date that is within three months of her last calving date. The six elose-bred daughters of Cacapon Leto 15th which have recently come into milk have a striking similarity in size and shape of udder, length of teats, and in body conformation. The daughters of Penshurst Romeo have produeed milk testing especially high for animals of the Ayrshire breed, a characteristic which was also evident in his daughters in another herd.

\section{Whole Milk is Costly as Calf Feed}

Thirty to forty thousand heifer calves are raised in the state each year at a total cost from birth to first calving of several million dollars. Sinee feed and labor costs amount to 80 to 94 percent of total eosts, studies and surveys were made of these factors in the Station dairy herd at Morgantown and also on 122 West Virginia farms in order to determine how these two eosts might be reduced.

In both the Experiment Station and survey studies it was found that the amount of labor expended per heifer deereased with (1) an increase in the number of heifers in the herd and (2) an increase in the number of pasture days per heifer. It should be of especial interest to West Virginia dairy farmers that the cost of raising heifer's ean be decreased through an increased use of good pasture.

The data presented indicate that West Virginia dairy farmers could reduce the cost of growing heifers by feeding less than the average amount of whole milk that is being fed. This is true especially of breeders of registered cattle who fed five times as much whole milk as was being fed to the Station herd. Where it is practical to do so, skimmilk or a satisfactory substitute could replace a portion of the whole milk.

\section{Sudan Better Filler than Sweet Clover}

A study of sweet clover and Sudan grass, as compared with and as a supplement to Kentucky bluegrass as a pasture for dairy cows, was carried on at the Reymann Memorial Farms. It was found that although the bluegrass usually gave just as many pasture days as did the other erops, there was a period during the latter part of the summer when it could not be eounted on to supply sufficient feed. To fill in this period, Sudan grass seemed to be superior to the sweet clover. It could be planted to come on at about the period when bluegrass was at its low point, and it would continue until frost. Sweet elover, during its 
first year', could not be eounted upon to give very mueh pasture and during its second year it was practically gone by the time bluegrass was at its low point. It was a satisfactory pasture for early spling but came on just when bluegrass was at its best. To supplement the bluegrass, therefore, Sudan grass seemed to be better suited than did sweet clover.

\section{MILK AND CREAM STUDIES}

M ARKED progress has been made in determining the causes and methW ods of preventing oxidized flavors in milk. Evidence that the presence of ritamin $\mathrm{C}$ prevents the derelopment of oxidized flavor was obtained by feeding tomato juice in the amount of two quarts daily to three eows known to be produeing suseeptible milk. This susceptibility diminished and disappeared after several weeks of this treatment but recurred when the feeding of tomato juice was discontinued. Similar results were also obtained from the feeding of pure vitamin $\mathrm{C}$ (Cebione) and lemon juice. Likewise in the ease of six cows which produced susceptible milk on a dry, barn-feeding regime the susceptibility disappeared when the animals were on pasture.

That the material oeeurring in milk whieh causes oxidized flavors is largely adsorbed on the fat globules is evident from a series of experiments in which ehanges in the adsorption equilibrium were produced. Homogenization, agitation at low temperatures, and freezing followed by thawing reduced or eliminated susceptibility to flavor development.

Valuable practical information on the handling of milk in pasteurizing and cooling for preventing oxidized flavor derelopment has been obtained as follows: (1) milk pasteurized, cooled, and handled thereafter withont contact with copper should not develop oxidized flavors, (2) eontanination of milk with copper after pastemization causes pronounced oxidized flavor, but the same amount of contamination before pasteurization causes only slight development of the flavor, and (3) free exposure to air on a surfaee type of eooler shows no tendency to inerease oxidized flavor development as compared with minimum exposure in an internal tubular type of cooler.

\section{Bitterness in Cream is Due to Bacteria}

Studies of the causes of bitter flavor in cream shipped to ereameries indicate that slow bacterial action resulting from holding the eream for long periods on the farm before shipment is largely responsible for the trouble. Secretion of lipase by the cow which is known to eause bitter and rancid flavors within twenty-four hours after milking was not an important factor in the cases investigated. 
$\mathrm{T}$

HE VARIETy TESTS include winter wheat, spring oats, winter balley, limited trials of spring barley, soybeans for both hay and seed, and date of seeding trials with winter barley. They are conducted in part at Morgantown, Lakin, and Kearneysville.

The dates of seeding which gave the highest arerage yields of winter barley were August 15 to 25 at Kearneysville, September 4 at Morgantown, and September 14 to 24 at Lakin.

\section{Canawa an Improved Winter Wheat}

A pure-line seleetion of winter wheat which was made in 1921 has shown high yielding ability both in rod-row trials and in solid drill plots and appears to have suffieient merit to walrant its introduction as a new variety. It was selected from a eommereial variety grown under the name of Canada Hybrid, and the pure-line strain has been named Canawa. It has praetically awnless spikes which droop when ripe, and the seed is short, semi-hard, and red in eolor. The new variety is deseribed in Bul. 272 of the Experiment Station.

Breeding experiments with field coln for smut resistance which have been in progress for some years at Morgantown have resulted in a number of selfed lines of corn which differ greatly in susceptibility to smut, both as to number of boils and their location. Topcrosses between 98 of these inbred lines and two of the best commercial varieties, Reid's Yellow Dent and Woodburn White Dent, were tested as to yield in 1935. Only 23 of these gave significant increases over the commereial strains. The topcrosses ranged in yield from 60 to 97 bushels of corn per acre as compared with 66 for the corresponding commereial strain.

Further toperosses using two of the best-appearing of the W'st Virginia imbreds and the best selfed lines from other states were tested in 1935,39 of the selfed lines being involved in one series of crosses and 55 in another. Several gave yields greatly exceeding that of the best commercial variety.

\section{Yellow Woodburn Corn is Sought}

Progress is being made in the attempt to produce a yellow Wroodburn variety, one which will combine the high yield of the Woodburn White Dent with the desired yellow endosperm color.

The results of an invcstigation reported elsewhere showed that the stalk and leaves of earless corn plants were richer in animal feed mutrients than the stalk and leaves of comparable plants which bore ears. How- 
ever, the total feed value of the normally-cared plants produced on a unit area was found to be greater than that of the earless plants produced on a comprable area of the same size.

Selections for resistance to bacterial wilt (Stewart's disease) have been continued among the selfed lines of commercial varieties of sweet corn. An attempt to seeure resistant early lines has also been made by crossing early suseeptible and late resistant lines, and these crosses have now been backerossed to the early variety, using only healthy plants whieh survired inoeulation with the wilt organism.

\section{Disease Resistance in Tobacco and Watermelon}

Studies of the inheritance of resistance in tobacco to rootrot eaused by Thielavia basicola, eonducted in cooperation with the Bureau of Plant Industry, U. S. D. A., show that disease resistance is heritable as a dominant or partially dominant character. Some of the hybrid strains appear to have higher leaf quality than either of the parents, which are two Standup Burleys, No. 10 Ba being resistant and Kelly being susceptible to rootrot. In all 126 resistant strains of hybrid origins were tested in 1935. Some of these in addition to resistance to rootrot appeared to possess better quality than either of the parents. Further and more extensive tests for quality will be neeessary.

Evidenee that resistance to wilt (Fusarium niveum) in watermelon is inherited has been obtained by comparing backerosses of hybrids to the resistant Russian parent and the suseeptible Fordhook parent. The resistance appears to be dependent on several factors, and since there is no elose linkage between resistance and any of the factors which determine desirable commercial qualities it should be possible to obtain a resistant melon of good quality. As a matter of faet a few of the families which descended from the eross Russian X Early Fordhook show some resistance and have fair quality as edible melons. The Russian parent whieh is entirely inedible and is quite distinctive in other characteristies has been found to have the same chromosome number as that reported for the commereial varieties.

The seareh for resistance among commercial watermelons has been aided by planting large numbers of the seed of several adapted varieties in soil thoroughly infested with several of the most virulent strains of the wilt organism. From several thousand seeds 20 plants were obtained which survived exposure to severe soil infestation both in the greenhouse and in the field and produeed fruit. The progeny of these plants is now undergoing further tests. 


\section{Acid Tolerance and Coumarin in Sweet Clover}

The sweet elover investigations which have as their object the production of strains having low eoumarin eontent and tolerance to acid soil conditions continue. Thirty-three of the most promising of the selfed strains which survived the winter of 1934-1935 were selfed in 1935 and planted in 1936 for further selection. New selfed material from several fields is also being tested so that the total of selfed lines under study now equals 117. Several plants from selfed lines grown on an aeid plot of $\mathrm{pH} 4.8$ survived and seeds from these have been sown back on the acid plot to determine the degree of their aeid toleranee.

Pekwa soybeans (selection I-21-7) has been renamed Kingwa and the strain (seleetion I-21-8) formerly grown under the name of Kingwa has been withdrawn from further distribution. This action seemed desirable, as is explained in Bulletin 273, because of the similarity of the two strains and the danger of eonfusing them.

\section{Winter Cover Crops Reduce Erosion}

The limited amount of level tillable land in West Virginia often makes it desirable to use short rotations. Corn and soybeans are commonly used because these erops furnish the kind of feed needed for livestoek. In such a rotation erops oceupy the land less than one-half of the year. During the winter months there is a considerable loss of nutrients by leaching and erosion. The growing of cover erops to furnish vegetative erops reduees losses, and plowing these under as green manures has a beneficial effect on the soil.

The results of 13 years' experiments with rye, rye-and-vetch, crimson clover, and sweet elover eover erops in a eorn-soybean rotation may be summarized as follows:

(1) Rye, rye-and-vetch, and vetch increased the yield of both corn silage and soybean hay. The increase was the greatest on the plots having a cover crop of rye and veteh.

(2) Crimson clover and sweet elover did not make satisfactory cover crops in this rotation at Morgantown. The winters were too severe for these erops under the conditions of this experiment.

(3) The results show only the effect due to reduction of losses by leaching and the inerease in available plant nutrients. Erosion losses on slopes would undoubtedly greatly inerease the beneficial effect of the cover erops.

(4) There were no significant differenees in total nitrogen content of the soil at the end of the experiment. All the soils showed some decrease in total nitrogen. 


\section{SOILS AND FER'TILIZERS}

Considerable atTention has been given to the problems of pasture $\checkmark$ land, which is of great importance in West Virginia since nearly 5 million aeres of land are devoted to pasture use. As a rule pastures have received little attention in the past and gencrally show evidenee of marked deterioration in recent years.

\section{Representative Pastures Studied}

In order to obtain first-hand information as to pasture conditions a somprehensive field study was made in 1935 with the help of the federal Soil Conservation Service. A total of 775 pastures in nine important pasture areas eomprising parts of 20 counties were examined as to the amount and kind of vegetation present, the soil type, depth of surface soil, amount of erosion, and degree of slope. Data in regard to carrying eapaeity and grazing practices were also obtained. More than 700 soil samples were also taken to make laboratory studies of the available phosphorus and acidity of the soils.

In the poorest of the nine areas an average of 5.3 acres of pasture was required per animal unit while in the best area only 2.5 acres were needed. The wide differences in earrying eapacity which were found were related to the type of vegetation present, only 10.6 percent of the pasture sod being eomposed of desirable grasses and legumes in the ponrest area, while in the best area this value was 46.9 pereent. Differences in soil type, degree of slope, and amount of erosion partly accounted

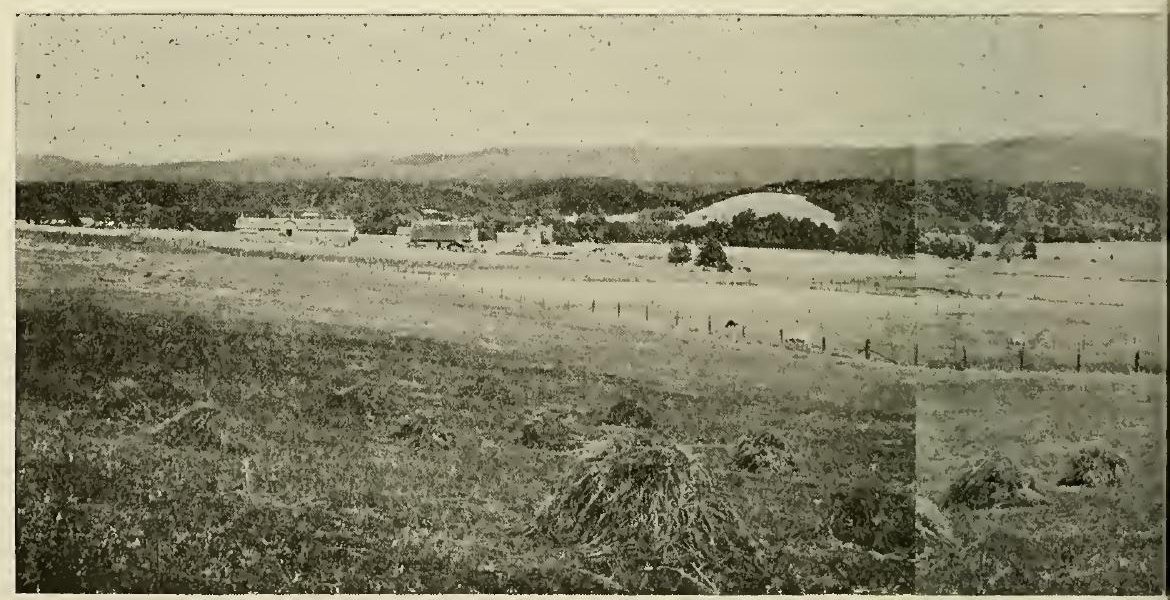

Extensive pasture experiments at the Reymann Memorial Farms and second-year sweet clo

(Photo by courtesy 
able phosphorus and percentage base saturation of the soil. An attempt to work out a formula whereby the gains measured by clipping experiments may be interpreted in terms of animal grazing units has given promising results. A summary of the results of the grazing experiment at Wardensville for the years 1933, 1934, and 1935 follows. The treatments were applied in 1933 and the results are an average for the three years. They indicate that the length of time the treatments will give results will determine to a large extent the profitableness of such treatments.

Number of $1000 \mathrm{lbs}$. cow days per acre

Lbs. gain in weight per acre

\section{CHECK}

66.1

131.9
L-P

93.3

194.3
I-P-K

128.1

261.8
L-P-K-N

145.1

286.1

\section{Lime and Fertilizer for Field and Forage Crops}

Experiments to determine the response of field and forage crops to fertilizers and lime have been in progress for several years and include (1) experiments with field crops involving a total of 303 plots at the Lakin Experiment Farm, begun in 1930, (2) experiments with alfalfa on seven soil types, begun in 1931, and (3) potato fertilizer experiments, begun in 1934. The potato studies are carried out jointly by the departments of agronomy and horticulture and are reported in the section dealing with vegetable erops.

In the experiments at Lakin the response to nitrogen, either in the form of green manure crops, cover crops, or nitrogenous fertilizers, has been marked. For example, the turning under of a cover crop of sweet clover was found to be the equivalent of applying 40 pounds of nitrogen in commercial fertilizers for corn and wheat during the first two years after being plowed under. Likewise the inclusion of clover and timothy in a rotation of corn and wheat gave increases in the yield of corn comparable to those obtained by applications of 40 pounds of nitrogen. The value of green manures in these experiments appeared to be attributable solely to their nitrogen content. However, in another experiment with potatoes, the cover crops turned under had a much greater value than could be attributed to the nitrogen turned under.

\section{Alfalfa's Response to Degrces of Liming}

While the alfalfa experiments have not been in progress long enough to give conclusive data, the results to date show increased vields from applications of 500 pounds of 20 percent superphosphate and 100 pounds of muriate of potash, the gains being greater as a rule from the phos- 
phate treatments. Higher rates of application were beneficial in all tests. Lime to bring the soil at a pH slightly below 6.0 increased the yields, but additional amounts had little effect. There is little doubt, however, that for the successful growth of alfalfa, phosphorus is necessary on most soils of the state.

In eontrast with these results of lime applications, however, were results obtained on the growth of alfalfa in small field bins. Here the yields of alfalfa at $\mathrm{pH}$ values slightly above 7.0 were approximately twice as high as at pH 6.0. The lime had been applied to the bins six or seven years previously, while only one to four years had elapsed in the field experiments. While the explanation for these differences is not entirely clear, the data suggest from a practical point of view that good growth of alfalfa may be obtained for a few years when a very acid soil is given only a portion of the lime needed but that eventually liming to a higher level will be necessary in order to get maximum yields.

Support for these conclusions is likewise found in studies of the effect of liming the subsurface and subsoil on the growth of alfalfa. The plots which received lime only in the surface three inches of soil made good growth during the first few years but the growth now is relatively poor. The evidence indicates that lime applied to the subsurface 8 to 16 inches of soil and the subsoil 16 to 24 inches has a marked influence on the minimum $\mathrm{pH}$ value of the surface soil at which satisfactory growth of alfalfa may be obtained.

Evidence of the slow downward movement of lime in soil was obtained from a study of the pasture plots mentioned previously. Practically no lime had penetrated to a depth of over three inches during $31 / 2$ years after the lime was applied. This was true also of the phosphorus added as superphosphate.

\section{Dolomitic Limestone as Filler}

Studies of acid-forming and neutral fertilizers which have received major emphasis at the West Virginia Station in recent years and which have resulted in the rather general adoption of non-acid forming mixtures through the use of dolomitic limestone fillers by fertilizer manufacturers have been continued. One phase of the study was planned to determine the value of rock phosphate and of dolomitic limestone as supplements in making fertilizers non-aeid-forming. It was found that roek phosphate and colloidal phosphate had practically no effect in modifying the acid-forming character of fertilizers, while ealcined phosphate, which is produced from rock phosphate in such manner that most of the 
phosphate becomes citrate soluble, had approximately two-thirds of its ealcium arailable for neutralizing soil acidity.

A very elose relationship was found between the rate of decomposition of dolomitic limestonc and the pH of the soil in the fertilized zone. Thus at p.H 5.8 only about 20 pereent of the 100-mesh dolomite was decomposed, while at pH 4.4 all of it was decomposed during the same period of time. The rates of decomposition of dolomitic limestones froin West Virginia, Ohio, Tenmessee, and Alabama were found to be praetieally the same.

The use of dolomitic limestone as a filler is valuable in supplying magnesium in the magnesium deficient soils of the Eastern states. The material should all pass the 20-mesh sieve and a large part of it the 60 mesh sieve if much benefit is to be derived during the first year. Material finer than 100-mesh when used in a mixed fertilizer liberated practically as much magnesium in the fertilized zone as did pure magnesium sulphate containing an equivalent amount of magnesium.

\section{PLANT DISEASES}

T

HE SUMMer of 1935 was partieularly favorable for the infeetion of red cedars by the apple rust disease with the result that very severe infeetion oeeurred in the experimental nursery. A number of the susceptible strains of red eedars were killed, and all but one of the strains which had shown resistance previously beeame infeeted. With the resistant strains, however, the infeetions were few in number and the galls were very small. It is believed that even under such unusually favorable eonditions as those of 1935 the amount of infection resulting on the resistant cedars would be of no economic importance as a source of infection for apples.

\section{Black Pox of Apple Identificd}

Previous studies of the group of bark diseases of apples which have commonly been known under the name of measles have led to the identification of the cause of one of these, the black-pox disease. The more recent studies have dealt particularly with the bark-necresis trpe of measles which is typical of the Delicious variety. Evidence indicating that this disease is most prevalent and severe during seasons of excessive heat and drought has appeared from field observations. It was found that those trees which were set in soils that bccome excessively dry suffered most severely, but attempts to produce the disease throng regulation of soil moisture and air temperature have so far failed. The new 
growth on trees enclosed in cloth cages showed no infection during three consecutive years, but it is not elear whether this may be due to the exclusion of organisms or the effect of the cloth in reducing transpiration.

The importance of after-harvest spraying for the control of secondary infection by cherry leaf spot was shown in 1934 in an orchard in Jefferson county, where the value of different sprays on a fixed schedule was determined. Rather severe infcetion and defoliation occurred when the after-harvest spray was omitted. The pink and petal-fall sprays were of greatest importance in preventing primary infection. A total of five sprays were applied in the complete schedule.

Further evidence of the high incidence of infection which results when young apple trees are planted on sites where old trees have died from black rootrot was obtained in experimental planting involving 165 trees. Approximately 40 trees were planted on each of four sites previously occupied by diseased trees. After thrce years exposure 60 percent of the trees were found to be infected, many of them so severely that they could not have survived another season. Attempts to find resistant stocks have been without success. Some 28 different stocks were inoculated in 1935 with the black rootrot fungus in pure culture, and all developed infection. There was no evident relation between vigor or lack of vigor of the trees and the severity of infection either in the case of natural exposure or of artificial inoculation.

\section{Soft-Rot and Colon Organisms Related}

Extensive studies of the group of bacteria which cause soft rots of plants have been made with the view of determining their relationships to each other and to the colon groups of bacteria which occur in animals. A total of 120 cultures were employed for physiological and pathological studies, and 58 were also studied serologically. The organisms showed marked variability. during the course of the tests in their ability to ferment various sugars, in the production of indole, in the reduction of nitrates, and other physiologic reactions. They also varied greatly at different periods in ability to cause rots of carrot, cabbage, and potato. Increase in range of pathogenicity through the use of an intermediate host was demonstrated in the ease of one organism which caused rot of carrot after passing through potato tissue although unable to do so previously. The studies point to an evident relationship between the soft-rot bacteria and the colon group.

Dissociation of the watermelon wilt fungus into types unlike the parent strain which had previously been found to occur in culture media, 
has now been demonstrated also to oceur commonly in soils. 'These dissociants differ in their ability to produce disease as well as in their type of growth, color, and other features. Evidence is also accumulating which shows that other wilt-producing fusaria may give rise to dissociants which are capable of attaching hosts other than those which were parasitised by the parent strain. Work on this problem has been aided through a grant from the National Research Council.

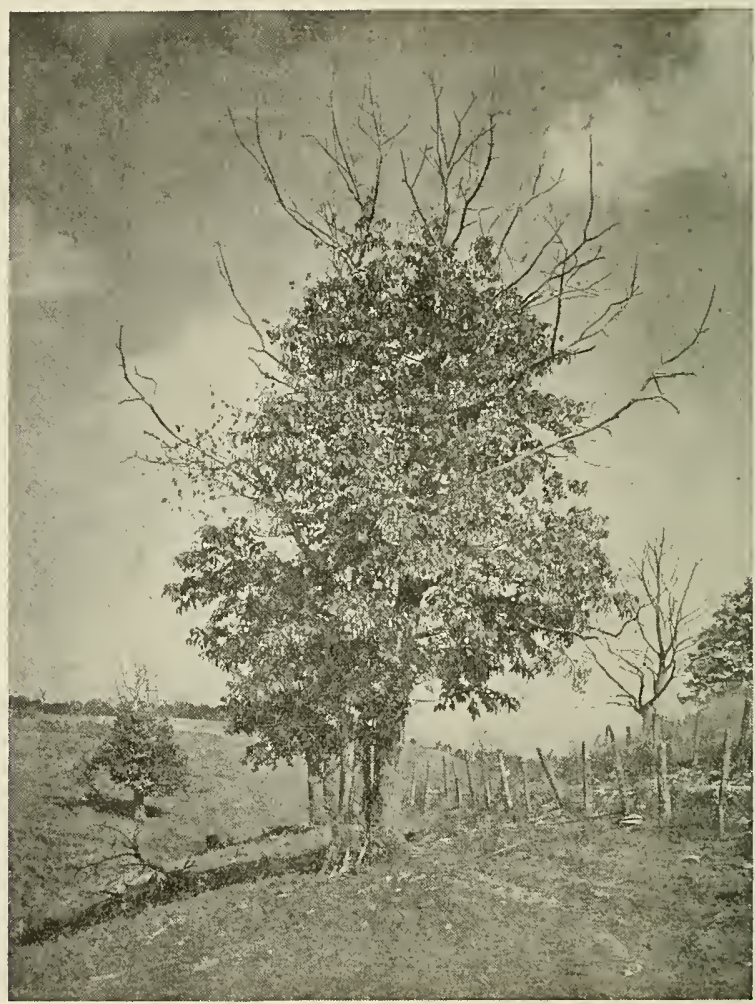

One of a small group of native chestnut trees which have survived the blight for more than 15 years. Such trees as these are being used as parent stock in the search for blight resistance. Note the comparatively dead tree in right background

Although the losses from the chestnut blight disease have been almost complete in West Virginia there are occasional chestnut trees still living and producing nuts which appear to possess some measure of resistance. For the past several years muts collected from such trees have been planted in the experimental nursery and about 1,000 seedlings 
ranging in age from one to threc years are now avajlable for testing. They will be inoeulated with the blight fungus in order to retermine what measure if any of resistance they may have.

Influence of Growth Substances in Fungi

Following the discovery that certain seeds ol seedlings of higher plants, especially the garden pea, contain a substance in very minute quantities which effects a marked influence on the growth of certain fungri as well as a separate and distinct substance which influences the production of sex organs, attention has been directed to studies of sources of these materials, their effects on a wide range of fungi, and their chemical properties and identifications. Some 200 representative fungi have been tested as to growth requirements and have been found to fall into two groups, those which require organic nitrogen and those which do not. The latter group is likewise separable into a group which can utilize nitrogen in the form of nitrates and a group which must obtain their nitrogen in the form of ammonium salts. Yeast extract proved to be uniformly good as a growth-promoting substance for ali fungi, and the nitrogenous extract of yeast proved equally effective for some species of fungi. Many of the so-called auxins described by other investigator's have been tested for growth promotion with some 80 species of fungi, and none has proved effective. It appears that growth in these fungi is controlled by some form or forms of nitrogen.

In contrast with its effect in promoting the growth of fungi, yeast extract is not very effective in promoting the development of sex organs. Pea extract is much more effective and induces sexuality in a great many fungi. Still other fungi are not affected by pea extract but are stimulated by substances present in grains. Some fungi have been found to be capable of synthesizing their own sex factors while others must depend on some extraneous source.

Although final identification of the sex-promoting substance in peas has not been made, the active substance has been purified to the stage where it contains no minerals, fats, carbohydrates, proteins, or nitrogenous material. It is effective in this stage at a concentration of one part per million in inducing abundant production of oogonia in Phytophthora cactorum.

\section{PHYSIOLOGY}

A S PREVIOUSLY REPORTED, the incidence of colds among students was A not affected by the intake of codliver oil or other rich sources of vitamin $\mathrm{A}$. There was, however, a significant reduction in the duration of colds. Further studies of vitamin-A deficiency in rats indicate an in- 
crease in water consumption during the early stages of the deficiency as compared with normal controls, an increased volume of urine voided, and an apparent retention of water in the tissues of the trunk. As the deficiency progresses these relations are reversed, suggesting as a function of vitamin A the regulation of water metabolism. Studies with dogs indieated a similar trend in water metabolism but only slight and probably not significant changes in salivary secretion during progressive vitamin-A deficiency.

\section{ENTOMOLOGY}

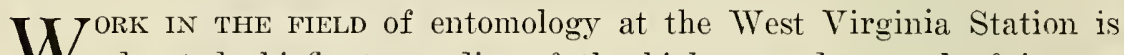
devoted chiefly to studies of the biology and control of insects which are of importance in commercial apple orchards. The relation of temperature to insect development is also under investigation, and tests of the efficieney of various insecticides in the control of insects attacking garden plants have been in progress for some years.

\section{Lead Arsenate Still Standard for Codling Moth}

The conclusions to be drawn from the studies of spray materials for eodling-moth control are that only arsenate of lead can be recommended generally in badly infested orchards. Other materials may, however, be substituted for arsenate of lead under conditions of slight or moderate infestation. This is true particularly of calcium arsenate. Nanganese arsenate, zinc arsenate, and zinc meta-arsenite also proved effective, but zine arsenate was definitely less effective and left residues too high above the tolerance for use without washing the fruit. Cuprons cyanide showed excellent killing power but was injurious to fruit and foliage. (The manufacturers have apparently "dropped" the product.)

In a study of various commercial bands and of bands receiving different treatments it was found that the most effective bands were produced by the so-called "hot-dip" process and that the quantity of betanapthol required could be reduced by adding aluminum stearate, thus reducing the cost. Oil of " 300 " viscosity was best suited for a mixture with a high load of beta-napthol, while oils down to "100" viseosity were more suitable for mixtures with a lighter load. Many commercial bands were found to be satisfactory.

While it is difficult to measure or demonstrate the value of bands in reducing codling-moth infestation it is apparent that the aggregate value of banding must be considerable. Their use has increased steadily and banding has become standard practice in good orchards. 


\section{Timing is Important in Case-Bearer Control}

Studies of the pistol case-bearer have continued with the object of establishing more effective, less expensive, and more convenient treatments. The most satisfactory treatment would be one applied during the dormant season, but such materials as have been tested did not prove effective at concentrations which were economical or entirely safe. A one-percent summer oil gave excellent results when used as an ovicide and it, seems likely that such sprays, which may be applied before the eggs have hatched, will replace the larvacides now in use which ean be used effectively only for a brief period after the eggs have hatched. A cheaper larvacide than the nicotine-penetrol combination and one equally effective has been developed by combining nicotine with summer oils. Timing of these sprays remains the most important factor in their effectiveness.

Because of the impossibility of distinguishing between the eggs of the injurious rosy aphis and green apple aphis and the comparatively harmless apple-grain aphis it has seemed desirable to develop methods for hatching eggs during the winter months so that the need for spraying could be established. It appears from the tests made that it will be entirely feasible to determine by pre-season hatching what aphids are present and the relative abundance of each.

Because of local interest in the use of barium carbonate for garden insects a series of tests was made of this material in comparison with other materiais for the bean beetle, cabbage worm, cucumber beetle, and blister beetle. Barium carbonate gave a fair degree of control of the bean beetle but was ineffective for cabbage worms and cucumber beetles. It was much less effective for blister bcetles than arsenicals. Freedom from foliage injury on beans in the use of barium carbonate tends to offset its higher cost and lower efficiency.

\section{Winter Temperatures and Insect Life}

Conclusions from the studies of the relation of temperature to insect development are that insects which winter in situations above the soil are affected by air temperature alone, while those which winter in the soil are governed solely by soil temperatures. Those which winter on the soil but in some sort of cover are less affected by air temperatures than those wintering above the soil and they may emerge from shelter when air conditions are unfavorable. Examples of these rules are found in the case of eggs of apple aphids, which frequently hatch and perish during periods of warm air temperatures before the apple buds hare 
opened sufficiently to serve as food. Nay beetles and eut worm and other moths often emerge in March and April, when air temperatures are such that they cannot live. The emergence of the bean beetle is brought about by moderate soil temperatures plus unseasonably warm day temperatures, and the insect may be killed by sharp decline in night temperatures. Failure of the beetle to appear in large numbers early in the past several seasons is attributed to conditions which brought them out of winter quarters too early, rather than to winter-killing in the usual sense of the term.

\section{FARM ECONOMICS}

STriking dirferences between appraisals by the Farm Credit Admin$\mathrm{S}$ istration and by county assessors are shown in a study of 600 farms in West Virginia. Land Bank loans or Land Bank Commissioner's loans had been made on each of these farms. Data on both the appraised value and the assessed value were obtained from the records of the Federal Land Bank of Baltimore, Maryland. Typical of the wide divergences of values placed upon the properties by appraisers and by assessors are the records of Greenbrier and Upshur counties.

Normal Value a Fair Basis for Assessment

For the 17 farms in Grcenbricr county for which records were obtained, the assessed value ranged from 17.5 percent to 79.4 percent of the appraised normal market value on which the loan was based. And for the 24 farms in Upshur county the assessed value ranged from 35.3 percent to 174.7 percent of the appraised normal market value.

It is held that assessments for taxation should be based on normal market value. These need not be the full market value but should be a uniform percentage of it.

Undertaken at the request of the State Relief Administration and carried on in cooperation with this body, a study was begun in 1934 of the Charleston area as a market for truck crops and farm produce. The purpose was to analyze the market demand in Charleston as a guide to the production of truck crops on the Red House homestead as well as by farmers in the Charleston area. Data were assembled showing the origins of products supplying the market, prices received for various products, and market preferences and practices. The study revealed that, in the main, West Virginia production fell far short of supplying this wholesale farm market. Prices received for the West Virginia-grown products usually were slightly below the average prices received for all of the commodity sold. 


\section{Power on West Virginia Farms}

The development of the use of animal and mechanical power for performing farm operations, together with the invention of machines through which this power might be applied more efficiently and effectively, has brought about revolutionary changes in the agricultural industry. The progress made during the past 100 years has eclipsed all success hitherto achieved in the application of power other than human muscle to agricultural production. Sinee the beginning of the twentieth century the increase in the use of mechanical aid in agriculture has been astoundingly rapid.

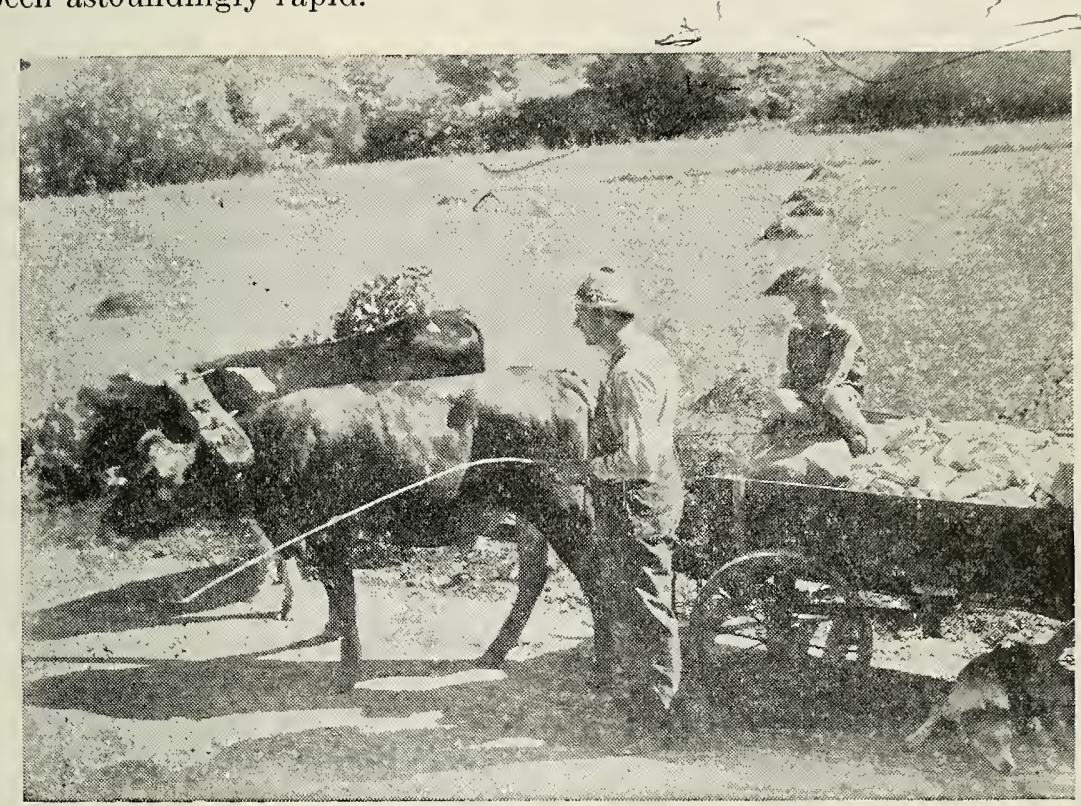

Ux teams may still be found in sections of West Virginia

The purpose of a study of the use of power on West Virginia farms was to make information available concerning costs and the extent of use of the various types of farm power. Data were obtained by personal visits to 441 farms in several seattered areas of the state. On 260 of these farms, horses furnished all the drawbar power; tractors were employed on 181 farms. Bulletin 267 of the Experiment Station gives a complete report of the study.

The problem of soil erosion has been recognized for years as ore seriously affecting agricultural and national welfare. It is only recently, however, that intensive and concerted effort has been made to arrive 
at practical methods of control. When the Spencer region was approved as a demonstration area in soil conservation, it was felt that study of the social and economieal eonditions of the people would have considerable value in carrying on the work and in forming a basis by which improvements brought about in the area as a result of the program undertaken might be measured adequately. In cooperation with the U. S. Department of Agriculture the Experiment Station undertook a study of social and economic conditions in the area before any effects of the demonstration had been realized. The study is to be reported after five years. Bulletin 269 of the Experiment Station is a record of the first survey, in which 772 farms were visited.

\section{Efficiency of Milk Plants and Producer-Distributors}

Fluid milk and eream are distributed in West Virginia by two important groups of retailers. Approximately one-half of the milk and eream is sold by milk plants which purchase practically all their supply from producers in their local market area. The remainder of the fluid milk and eream consumed is sold by producer-distributors. Any adequate study of the cost of milk distribution must therefore include these two groups of distributors.

Complete cost and income records were obtained from 22 milk-distributing plants in the state for the year 1933. Costs were analyzed showing the various costs ineurred in distributing milk in the state, the price paid for milk, the dealer's spread, and average receipts. Results were published in Bulletin 266. Sinee a large percentage (more than 50 percent in some markets) of the milk is distributed by producer-distributors, a cost route was begun in 1934 in the Wheeling, Morgantown, Fairmont, and Clarksburg markets to determine the cost of distributing milk for this group. The average cost of distribution by 75 producerdistributors was $\$ 1.76$ per 100 pounds of milk-equivalent snld, the range being $\$ 1.06$ to $\$ 3.39$. The average cost of nine plants in the same markets was $\$ 192$ per 100 pounds of milk-equivalent. This difference is accounted for by the following factors of difference in operation:

(a) The average wage rate for the distributing p'ants was $37.8 \mathrm{e}$ per hour, while for the producer-distributor it was $24.6 \mathrm{e}$;

(b) The distributing plants had a cost for pastemrization which was not incurred by producer-distributors.

(c) Plants had a higher real estate and equipment investment per ewt. of milk sold than did the producer-distributors ; 
(d) Plants, in purchasing all milk offered for sale by their producers, had to market a larger proportion in the form of surplus milk than was the case with the producer-distril)utors;

(e) Plants make special deliveries and are equipped to render additional services to the consumer, not rendered by the producer-distributor. Extra charges for rendering additional services may not amount to the total cost of such services.

The producer-distributors, in addition to being able to distribute their milk at a lower cost, are also in a position to retain control of it until it reaches the consumer. Because of the comparatively small investment and large percentage of the labor which is family and operator's labor they can also adjust their costs to the price of milk more readily than can the plants.

This project is being continued in the Huntington, Charleston, and Parkersburg markets.

To investigate the cost of producing milk in West Virginia, records were obtained from 1934 to 1935 by the route method from 51 cooperators in the area supplying milk to Morgantown and Fairmont.

The net costs of production were found to be $\$ 1.92$ per hundred pounds of $4 \%$ milk in the Morgantown market, and $\$ 1.91$ in the Fairmont market. The least efficient herds studied were found to have low average production per cow, partly because the cows were not bred for high production, and partly because their feed provided insufficient amounts of protein. Breeding for higher production and greater use of legume hay are much needed.

There were two distinct groups in the Morgantown market, depending on the price received for their milk. The one group received an average of $\$ 2.43$ per 100 pounds of $4 \%$ milk. Their average cost was $\$ 1.95$, leaving a return of $39 \mathrm{c}$ per hour of labor. The other group received an average price of $\$ 1.69$ per 100 pounds of $4 \%$ milk. Their average cost was $\$ 1.89$, resulting in a labor return of $10 \mathrm{c}$ per hour.

In the Fairmont market the average price received was $\$ 1.58$. The average cost was $\$ 1.91$, and the labor return was $4 \mathrm{c}$ per hour.

A similar study is in progress with 45 cooperator's in the Charleston and Huntington markets.

\section{Facts for the Conservation Program}

A project dealing with regional adjustments in agriculture, in which the Experiment Station, the Bureau of Agricultural Economics, and the Agricultural Adjustment Administration cooperated, was under the di- 
rection of the department of farm economies. This was in fact a station project in which all departments and many staff members enoperated. The task of the project was to construct a plan for land use which, if carried out, would decrease or stop erosion and conserve agricultural resources. The merits of the plan were tested by an ineome analysis. The plan agreed upon called for a reduction in erop land of about 17 percent, in pasture land of about 10 pereent, with corresponding increases in forest land. The adoption of somewhat better eultural management practices, even with this reduced crop and pasture aereage, normally would provide a larger total production and higher net farm income than at present.

This project, along with similar projeets in the other states, was designed to furnish the Agricultural Adjustment Administration some basie faets for use in formulating the Agricultural Conservation program. A revision and refinement of the data submitted to the Agricultural Adjustment Administration is now under way.

As one part of this project the area of the state was divided into 4 slope elassifications, and slope maps were prepared for each eounty. A land class map was prepared for each eounty and for the state. Relationship between soil type, erosion, and slope was the basis on which the map was prepared. It is now in the proeess of further refinements.

In order to obtain some basie information needed in connection with farm budgeting required by the regional adjustment project a survey was made of farms in the state with the objeet of learning the inputs of labor, fertilizer, and purchased feeds, as well as outputs of crops and livestock. Records obtained on 716 farms have been summarized to show (1) labor requirements per erop acre, (2) kind and amount of maehinery used, (3) yield and disposal of crops, (4) labor requirements per unit of livestock, (5) management practices on livestock, and (6) productivity of livestock. A manuscript presenting the results of this survey has been prepared and will be published soon.

\section{Our Changing Agriculture}

From the standpoint of location and climatic conditions, West Virginia is ideally situated for agricultural development, but because of such factors as topography, soils, industrial development, and the abundance of coal, timber, oil, and gas, agriculture has been retarded. The faet that the state is so rich in natural resourees and that land owners over a long period have derived ineome from royalties and leases, has tended to detract from the attention paid to agricultural possibilities and to the eonservation of soil resources in many areas. 
Data have been collected and graphs prepared showing changes in the acreage, yield per acre, and total production of the more important crops produced in the state, covering a period of the past 65 years. Datil relative to numbers of each of the various classes of livestock were also gathered and plotted.

Census data were also tabulated for the state by counties for each census year since 1880, showing acreage, yield per acre, and total production of each of the important crops. The number's of cach class of livestock in the various counties were similarly tabulated, as were also population, farm values, data on land utilization, number of farms, production of milk, eggs, and wool, and other pertinent information. 'This information has been compiled in Bulletin 276 of the Experiment Station, entitled "Trends in West Virginia Agriculture."

For three years a study of deep tillage was carried on with the purpose of measuring the effectiveness of such tillage in moisture retention and in the promotion of erop growth. A four-year rotation of corn, potatoes, and alfalfa was used. Little advantage was shown for deep tillage over ordinary cultural methods either in moisture retention or in increased yields. Such conditions as ununiformity in the soil and extremely dry seasons undoubtedly affected the results as did also the type of soil.

In order to delineate and describe the various types of farming areas in West Virginia, a project has been undertaken jointly by the Station and the federal Bureau of Agricultural Economies.

Census data were analyzed as a basis upon which to divide the state into its 12 more or less distinct type-of-farming areas. Additional information was obtained from approximately 800 labor income and farm practice records taken in various counties of the state during the summer of 1934. A manuscript entitled "Types of Farming in West Virginia" is being prepared and will be published soon. It will present data basic to agricultural planning and program building.

\section{Staff Changes}

Promotions within the research staff during the biennium include C. R. Burnham, associate geneticist; T. B. Clark, assistant poultry husbandman; I. J. Duncan, assistant agricultural chemist; W. C. Brown, assistant in dairy husbandry ; Edwin Gould, assistant entomologist; L. J. Manus, assistant in dairy husbandry; T. C. McIlvaine, associate agronomist; W. H. Pierre, agronomist and head of the department of agronomy and genetics; and K. C. Westover, associate horticulturist. 
New appointments include M. A. Abrahamsen, assistant farm ceonomist; E. P. Brasher, assistant in horticulture; W. M. Broadfoot, assistant in agronomy; L. F. Hermamn, assistant in farm economies; J. A. Rigney, assistant in agronomy ; and F. C. Weitzell, assistant farm econonist.

During the same period L. P. Batjer, assistant horticulturist. L. S. Bennett, assistant in agronomy, C. H. Bruce, assistant in farm economies, R. J. Garber, agronomist, E. N. McCubbin, assistant in horticulture, H. E. Knowlton, horticulturist, R. O. Stelzer, assistant farm economist, and L. M. Thurston, associate dairy husbandman, resigned.

\section{Publications of the Biennium 1934-36}

\section{BULLETINS AND CIRCULARS}

Bul. 261. European canker of black walnut and other trees. J. M. Asheroft. Technical. $60 \mathrm{pp}$. July 1934 (out of print).

Bul. 262. Identification of Phytophthora species. L. H. Leonian. Technical, $36 \mathrm{pp}$. Sept. 1934.

Bul. 263. Aiding West Virginia agriculture through researeh (Biennial report of: the director, 1932-34). General, 44 pp. Dec. 1934.

Bul. 264. Copper sulphate as an anthelmintic for sheep. J. H. Rietz. Technical, $20 \mathrm{pp}$. March 1935 (out of print).

Bul. 265. Some factors affecting the influence of soybeans, oats, and other crops on the succeeding erop. D. R. Dodd and G. G. Pohlman. General, 24 pp. April 1935.

Bul. 266. Milk-distribution costs in West Virginia: I. A study of the eosts incurred by 22 plants during 1933. R. O. Stelzer and L. M. Thurston. General, 36 pp. April 1935

Bul. 267. Power on West Virginia farms. F. D. Cornell, Jr. General, 44 pp. June 1935.

Bul. 268. Milk-production costs in West Virginia. L. F. Herrmann, R. O. Stelzer, and G. A. Bowling. General, 32 pp. Fbr. 1936.

Bul. 269. A social and economic survey of the Spencer soil-conservation area. General, 36 pp. April 1936.

Bul. 270. Milk-distribution costs in West Virginia: II. A study of the costs incurred by 75 producer-distributors in the Clarksburg, Fairnont, Morgantown, and Wheeling markets for a twelve-month period during 1934-1935. W. W. Armentrout and R. O. Stelzer. General, 32 pp. June 1936.

Bul. 271. Mass feeding of sheep with copper sulphate and salt to control gastrointestinal parasites. J. H. Rietz. Technical. $12 \mathrm{pp}$. June 1936.

Bul. 272. Canawa - a new variety of soft red winter wheat. R. J. Garber and L. S. Bennett. General, 8 pp. June 1936.

Bul. 273. Kingwa soybeans. R. J. Garber. General, 4 pp, June 1936.

Bul. 274. Color of lean of beef as affected by grass and grain feeding. J. H. Longwell. General, 8 pp. June 1936.

Bul. 275. Thirteen years' results with cover erops. G. G. Pohlman and H. O. Henderson. Technical, 12 pp. June 1936.

Cir. 68. Progress in research at Reymann Memorial Farms. G. A. Bowling. 20 pp. Jan. 1935. 
Cir. 69. Growing grapes in West Virginia. H. F. KnowIton and W. H. Childs. 24 pp. March 1935.

Cir. 70. The periodical cicada in West Virginia. W. E. Rumsey. 8 pp. May 1935.

Cir. 71. Lime - its need and use in West Virginia. W. II. Pierre and G. G. Poh!man. 24 pp. March 1936.

\section{MIMEOGRAPHED CIRCULARS}

No. 10. Food requirements, food production, and amount of land for a subsistence homestead. D. W. Parsons. Aug. 1934.

No. 11. Variety and strain tests of vegetahle erops at the Lakin Experiment Farm during 1934. K. C. Westover, T. C. MeIlvaine, and E. N. MeCubbin. Jan. 1935.

No. 12. Variety and strain tests of vegetable erops at the Lakin Experiment Farri during 1935. K. C. Westover, T. C. MeIlvaine, and E. N. MeCubbin. Jan. 1936.

No. 13. Variety and strain tests with some vegetable erops at the Arthurdale Experiment Farm at Reedsville during 1935. E. N. McCubbin and K. C. Westover. Feb. 1936.

No. 14. Rations for chicks. T. B. Clark. May 1936.

\section{SCIENTIFIC PAPERS}

No. 132. Hazel C. Cameron and G. S. Dodds. Studies on experimental rickets in rats. Amer. Jour. Anat. 55, 1: 135-165. July 1934

No. 133. K. C. Westover and E. N. MeCubbin. The influence of soil types on results from paper-muleh trials with the pepper and egg-plant. Proc. Soe. Hort. Sci. 30: 465. 1933. Also Gartenbauwissenschaft 8, 4: 573-580. 1934.

No. 134. A. P. Dye. Pruning greenhouse tomatoes. Proc. Amer. Soc. Hort. Sci. 30: 510.1933.

No. 135. Leif Verner. Effects of nitrate fertilization on apple fruits. Proc. Amer. Soc. Hort. Sci. 30: 32-36. 1933.

No. 136. R. J. Garber and M. M. Hoover. Dehulled seed, glume color, and reaction to smut in a certain oat cross. Jour. Amer. Soc. Agron. 26, 8: 673-680. Aug. 1934.

No. 137. Leif Verner. A simplified method of determining freezing-point depressions of apple tissue with the Beckmann apparatus. Proc. Amer. Soc. Hort. Sci. $31: 33-34$. 1934.

No. 138. L. H. Leonian. Control of sexual reproduction in Phytophthora cactorum. Amer. Jour. Bot. 23, 3: 188-190. March 1936.

No. 139. R. J. Garber, M. M. Hoover, and L. S. Bennett. The effect upon rield of cutting sweet clover (Melilotus alba) at different times and at different heights. Jour. Amer. Soc. Agron. 26, 11: 974-977. Nov. 1934.

No. 140. L. M. Thurston. A study of the relation of materials adsorbed on the fat globules to the richness of flavor of milk and certain milk products. Jour. Dairy Sci. 18, 2:131-137. Febr. 1935.

No. 141. L. M. Thurston, W. C. Brown, and R. B. Dustman. Oxidized flavor in milk: I. The probable relation of lecithin to oxidized flavor. Jour. Dairy Sei. 18, 5:301-306, May 1935.

No. 142. R. J. Garber and M. M. Hoover. Influence of corn smut and hail damage on the yield of certain first-generation hybrids between synthetic varieties. Jour. Amer. Soc. Agron. 27, 1: 38-45. Jan. 1935.

No. 143. Leif Verner. A physiological study of cracking in Stayman Winesap apples. Jour. Agr. Res. 51, 3: 191-222. Aug. 1, 1935.

No. 144. Hazel C. Cameron. The effect of vitamin-A intake upon the incidence and severity of colds among students. Jour. Amer. Dietetic Ass'n. 11, 3: 189-204. Sept. 1935. 
No. 145. W. H. Childs. The effect of rainfall during the picking season on size and yield of certain strawberry varieties. Proc. Amer. Soc. Hort. Sci. 32: 420423. 1934.

No. 146. A. H. Van Landingham, H. O. Henderson, and G. A. Bowling. Studies on the chemical composition of the blood of dairy eattle: I. The effect of age and phosphorus intake on the ealeium and inorganic phosphorus content of the whole blood of dairy heifers. Jour. Dairy Sci. 18, S: 557-572. Aug. 1935.

No. 147. R. J. Garlocr. Analysis of variance of corn yields obtained in croprotation experiments. Jour. Amer. Soc. Agron. 27, 6: 480-485. June 1935.

No. 148. C. R. Orton. The dissociation of Fusarium in soil. Bull. Torrey Bot. Club. 62: $413-420$. Oct. 1935.

No. 149. L. H. Lcomian. The effect of auxins upon Phytophthora cactorum. Jour. Agr. Res. 51, 3: 277-286. Aug. 1, 1935.

No. 150. C. R. Orton and W. D. Henry. An internal necrosis of bean seers. Phytopath. 25, 7: 726-728. July 1935.

No. 151. J. R. Taylor, Jr., and W. H. Pierre. Non-acid forming mixed fertilizers: I. Their effect on certain chemical and biological changes in the soil-fertilizer zone and on plant growtl. Jour. Amer. Soc. Agron. 27, 8: 623-634. Aug. 1935.

No. 152. W. H. Pierre and G. M. Browning. The temporary injurious effects of excessive liming of acid soils and its relation to the phosphate nutrition of plants. Jour. Amer. Soc. Agron. 27, 9: 742-759. Sept. 1935.

No. 153. J. R. Taylor, Jr., and W. H. Pierre. Non-acid forming mixed fertilizers: II. The value of dolomitic limestone supplements of different degrees of fineness as measured by the inerease in water soluble magnesium in the soil. Jour. Amer. Soc. Agron. 27, 9: 764-773. Sept. 1935.

No. 154. Hazel C. Cameron. Salivary secretion and the physiological mechanism of avitaminosis-A. Amer. Jour. Physiol. 115, 1: 210-214. March 1936.

No. 155. L. H. Leonian. The effect of auxins from some green algae upon Phytophthora cactorum. Bot. Gaz. 97, 4: S54-859. June 1936.

No. 156. T. B. Clark. A study of mean egg weight when grain is hopper-fed. Poult. Sci. 25, 1: 27. Jan. 1936.

No. 157. L. S. Bennett. Studies on the inheritance of resistance to wilt (Fusarium niveum) in watermelon. Jour. Agr. Res. 53, 4: 295-306. Aug. 15, 1936.

No. 158. R. J. Garber, R. B. Dustman, and C. R. Burnham. Yield and composition of eared and carless maize plants in a selfed line segregating barren stalks. Jour. Amer. Soc. Agron. 28, 2: 85-91: Febr. 1936.

No. 159. H. E. Knowlton. The relative abundance of pollen production by varieties of apples. Proc. Amer. Soc. Hort. Sci. 33: 7-9. 1935 (May 1936.)

No. 160. T. C. MeIlvaine and R. J. Garber. Inheritance of resistance to rootrot in tobaceo caused by Thielavia basicola. Jour. Amer. Soc. Agron. 2S, 4: 279-2S3. April 1936.

No. 161. L. P. Batjer. Croteh angles as affected by the method of training young apple trees. Proc. Amer. Soc. Hort. Sci. 33: 36-38, 1936.

No. 162. I. J. Duncan and R. B. Dustman. The anthocyanin pigment of the winesap apple. Jour. Amer. Chem. Soc. 5S: 1511-1514. 1936.

No. 163. R. J. Garber. Kingwa soybeans. Jour. Amer. Soc. Agron. 28, 6: 457-45\%). June 1936.

No. 164. A. H. Van Landingham, H. O. Henderson, and G. A. Bowling. Studies on the chemical composition of the blood of dairy cattle: II. The effect of phosphorus content of whole blood of dairy heifers during the period of first gestation and lactation. Jour. Dairy Sci. 19, 9: 597-609. Sept. 1936.

No. 165. R. B. Dustman. The storage of black-walnut kernels. Food Res. 1, 3: 247-253. May-June 1936. 


\section{Current Projects}

\section{AGRONOMY AND GENE'TICS}

Corn genetics and brecding (B J 3)

Variety testing of corn, wheat, oats, and soybeans ( $\mathrm{S}$ 6)

Soil survey work in West Virginia (S 8) Cover crop experiments (S 9; eoop. Dairy Husbandry)

Alfalfa investigations (S 10)

Crop rotation experiments (S 11)

Availability of phosphorus compounds (S 12)

Sweet-clover investigations (S 13; coop. Agricultural Chemistry)

Crop responses to varions fertilizers ( $\mathrm{S}$ 14 ; eoop. Horticulture)

Production of farm and garden crops on subsistence homestcads (S 32; coop. Hortieulture)

Breeding tobacco for resistance to rootrot and high yield ( $\mathrm{P} 1$; coop. U.S.D.A.)

Soil acidity and plant growth (P 2)

Pasture fertilization studies ( $\mathrm{P} 3$; CoO?. Dairy Husbandry and U.S.D.A.)

Fusarium wilt of watermelon (P 18; coop. Plant Pathology)

\section{ANIMAL HUSBANDRY}

Factors affecting the weight of hen's eggs (A 7)

Improving market grades of turkeys by cross-breeding (B J 5)

Effect of rations and methods of feeding grain on egg production (S 15)

Battery rations for growing chicks (S 17)

Relative values for growth of the proteins of a number of feeds used in poultry rations ( $\mathrm{P} 4$; coop. Agricultural Chemistry)

Breed as a factor in sheep production and quality of products produced ( $P$ 5 ; coop. U.S.D.A.)

Investigations concerning treatment for stomach and lung worms in sheep and cattle $(i \quad 6)$

Utilization of pastures in finishing yearling steers and heifers (P 7; cool). U.S.D.A.)

Corn silage studies (P 22; coop. Agricultural Chemistry)

\section{CHEMISTRY (AGRICUITURAL)}

Pigmentation and ripening of fruits (A 3)

Miscellaneous ehemical investigations (S 5)
Variability in eomposition of different skeletal parts of experimental animals P 20)

\section{DAIRY IIUSTANDRY}

Cost of raising dairy heifer's in West Virginia (S 20)

Growth study with Ayrshire cattle (S 21)

Different varicties of pasture for mills production (S 22; coop. Agronomy)

Water consumption of dairy animals (S 23)

Effects of quantity of coneentrates on longevity and productivity of daily cows (S 33)

Effect of low calcium and low phosphorus rations on growing dairy heifers ( $\mathrm{P}$ 8: coop. Agricultural Chenistry)

Causes and methods of prevention of oxidized flavors in milk (P 23; coop). Agrieultural Chemistry)

Causes of poor quality in cream transported in less than car lots (P 24)

Transmission of milk and butterfat production and body conformation by (lairy sires (P 14; coop. U.S.D.A.)

Comparison of alfalfa and timothy hay with and without corn silage for dairy cattle (P 25)

\section{ENTOMOLOGY}

Relation of temperature to insect li1's (A 1)

Biological control of codling moth (B J 13 ; coop. U.S.D.A.)

Miscellaneous insect and insecticide studies (S 24)

Biology and control of insects of majur importance in commercial orchards in West Virginia (P 9; coop. Marylınt. Pennsylvania, Virginia, and U.S.D A.)

\section{FARM ECONOMICS}

Regional adjustment in farming (B $\mathrm{J}$ 4 ; coop. Agronomy and U.S.T.A.)

Poultry as a farm enter 1 rise (S 26)

Comparison of loan appraisals on real estate with assessments ( $\mathrm{P} 10$ )

Economic and social development of families in Roane and Wirt counties as affected by the soil crosion control program (P 13; coop. U.S.D.A.)

Cost and eficiency of milk distribution (P 27; coop. Dairy Husbandry)

Cost of milk production ( $\mathrm{P} 2 \mathrm{~S}$; cuop. Dairy Husbandry) 


\section{HORTICULTURE}

Sterility studies with the apple (A 2)

Hardiness studies of the fruit buds of peach (A 4 ; eoop. Agrieultural Chenistry)

Misecilaneous hortieultural investigations (S 27)

Cultural treatments and fertilizers for fruits (S 2S)

Variety tests of tree and small fruits ( $\mathbf{S} \quad 29$ )

Training and pruning fruit trees (S 30)

Variety and strain studies of vegetables (S 31)

Green manure rotations for upbuilding and maintaining soil fertility in vegetable erop production (P 11)

Improvement of fruit-tree rootstocks ( $P$ 16 ; coop. U.S.D.A.)

Climatie and soil factors affecting fruit produetion in West Virginia ( $\left.\begin{array}{l}\mathbf{P} \\ 17\end{array}\right)$

\section{PHYSIOLOGY}

Relation of vitamin $\mathrm{A}$ intake to commou colds ( $\mathrm{P}$ 15)

Histology and bone growth in vitamin deficient animals (P 26)

\section{PLANT PATHOLOGY}

Apple rust (A 5)

Effect of environment upon morpholog: and parasitism in fungi (A 6 )

Nature and effeet of substanees whicin induce or stimulate growth and sexuality in fungi (B J 2)

Forest tree diseases (S 18)

Miscellaneous plant-disease investigations (S 19)

Apple measles (P 19)

Black rootrot of apple (P 21) 
